\title{
Phytochemical screening and in vitro antioxidant activity of Pistacia lentiscus berries ethanolic extract growing in Algeria
}

\author{
Djamila Belhachat ${ }^{\mathrm{a}, *}$, Fatiha Aid ${ }^{\mathrm{b}}$, Lakhdar Mekimene $^{\mathrm{a}}$ and Messaouda Belhachat ${ }^{\mathrm{c}}$ \\ ${ }^{a}$ Département de Technologie Alimentaire, École Nationale Supérieure Agronomique (ENSA), El-Harrach, \\ Algiers, Algeria \\ ${ }^{\mathrm{b}}$ Faculté des Sciences Biologiques, Université des Sciences et de la Technologie Houari-Boumediene (USTHB), \\ El Alia Bab Ezzouar, Algiers, Algeria \\ ${ }^{\mathrm{c}}$ East China Normal University, Shanghai, China
}

Received 14 July 2017

Accepted 8 September 2017

\begin{abstract}
.
BACKGROUND: The synthetic antioxidants are used routinely in foods especially those containing oils and fats to protect them against oxidation. Among the synthetic types, the most frequently used are butylated hydroxyl anisole (BHA), butylated hydroxyl toluene (BHT), propyl gallate (PG) and tert-butyl hydroquinone (TBHQ). These compounds have been reported to be dangerous for human health. Thus the search for effective, natural compounds with antioxidant activity has been intensified in recent years to replace the synthetic products.

OBJECTIVE: The aim of the present study is to investigate the phytochemical composition, quantify the total phenolic and flavonoid contents and to study the in vitro antioxidant potential of berries ethanolic extract of $P$. lentiscus.

METHODS: P. lentiscus berries were subjected to different chemical tests for the detection of phytoconstituents of the Algerian variety. The total phenolic and flavonoid contents were also determined using standard methods. Moreover, the antioxidant activity was assessed by using 2,2-diphenyl-1-picrylhydrazyl (DPPH-) assay, 2,2'-azino-bis-(3-ethylbenzthiazoline-6sulphonic acid) (ABTS-+) assay and reducing power activity assay. Here, (BHT) was used as standard antioxidant.

RESULTS: Phytochemical screening revealed that the berries contained phenolic compounds, flavonoids, anthocyanins, leucoanthocyanins, phlobotannins, tanins, saponins, terpenoids, proteins and mucilage while alkaloids, quinones and carotenoids are absents. The P. lentiscus berries extract was found to contain a high amount of total phenols, flavonoids. The berries ethanolic extract of $P$. lentiscus possess strong scavenging activity against DPPH., (ABTS-+) free radical scavenging activity and reducing power. The antioxidant proprieties may be attributed to the presence of high phenolic and flavonoid compounds. CONCLUSION: $P$. lentiscus is a potential source of natural antioxidants and other phytoconstituents, which justifies its uses in folk medicines.
\end{abstract}

Keywords: P. lentiscus, antioxidant activity, phytochemical screening, DPPH· assay, ABTS-+ assay, reducing power

\footnotetext{
${ }^{*}$ Corresponding author: Djamila Belhachat, Département de Technologie Alimentaire, École Nationale Supérieure Agronomique (ENSA), El-Harrach, Algiers, Algeria. E-mail: djamilaina@hotmail.com.
} 


\section{Introduction}

Plants are a large source of new bioactive molecules with therapeutic potentials [1-5]. Many studies carried out have shown that the medicinal properties of plants come from the presence of bioactive agents in their extracts [6-9]. The most important elements are alkaloids, flavonoids, vitamins, tannins, essential oils, organic acids, resins, fat oils, saponins and polysaccharides [10,11]. Reports indicate that there is an inverse relationship between the dietary intake of antioxidant-rich foods and the incidence of human disease [12, 13]. However, synthetic antioxidants, such as (BHT) and (BHA), have been widely used as antioxidants in the food industry and may be responsible for liver damage and carcinogenesis [14, 15]. For this reason, interest in the use of natural antioxidants has increased. Epidemiological studies have indicated the relationship between the plant antioxidants and reduction of chronic diseases [16-18]. Therefore, the development and utilization of more effective and non-toxic antioxidants from natural products are recommended, not only for the food and drug storage, but also for the nutritional and clinical applications. A great deal of effort has focused on using available experimental techniques to identify natural antioxidants from medicinal plants [19]. The Mediterranean region is relatively rich with plants (between 15,000 and 20,000 species) [20]. Algeria, a North African country with a large variety of soils (littoral, steppe, mountains and desert) and climates, possesses a rich flora (more than 3,000 species and 1,000 genders) [21], it has an immense biodiversity. Pistacia lentiscus L. is an aromatic evergreen shrub belonging to the Anacardiaceae family, largely distributed in the Mediterranean basin [22]. Aerial parts of $P$. lentiscus have traditionally been used in the treatment of hypertension, coughs, sore throats, eczema, stomach aches, kidney stones and jaundice. They possess stimulant and diuretic properties [23]. The fruits, galls, resin and leaves of P. lentiscus have a long tradition in folk medicine dating from the times of the ancient Greeks [24]. Several studies focused on the phytochemical composition of the resin, the leaves and the galls essential oil of P. lentiscus [24-28] and also on its antioxidant activity [29,30], but in contrast, fewer studies are related to the composition and antioxidant activity of the berries of P. lentiscus [31-33].

The aim of this study was to investigate the P. lentiscus berries growing in Algeria for its phytochemical composition, DPPH radical scavenging activity, ABTS activity and reducing power activity to explore their potential pharmaceutical and functional food uses.

\section{Materials and methods}

\subsection{Plant materiel}

The berries of P. lentiscus were collected in October 2014 from Bouira region in Algeria. The plant material identification was carried out according to the new flora of Algeria [34]. The P. lentiscus berries were dried at room temperature. After drying, the aerial part was ground with a coffee grinder to obtain a fine powder and stored in paper bags at $4^{\circ} \mathrm{C}$ until their use.

\subsection{Preparation of the extract}

Ethanolic extract was prepared from $20 \mathrm{~g}$ of the dried and powdered plant with $200 \mathrm{ml}$ of absolute ethanol (Ethanol 95\%) in a Soxhlet apparatus for 6 hours. Then, the solvent was evaporated using a rotary evaporator at $65^{\circ} \mathrm{C}$. Finally, the residue was lyophilized, weighed and kept in the dark at $+4^{\circ} \mathrm{C}$ until further analysis.

\subsection{Phytochemical screening}

Phytochemical analysis of the berries of P. lentiscus was carried out using the standard protocols for the presence of phenolic content, flavonoids, alkaloids, saponins, antocyanins, leucanthocyanins, phlobatannins, 
tannins, terpenoids, quinones, proteins, carotenoids and mucilage. Detection of these phytochemicals was based on visual observation following color change or formation of a precipitate after the addition of specific reagents.

\subsection{Total phenolic content}

Total phenolic constituents of plant extracts were performed employing the literature methods involving Folin-Ciocalteu reagent and gallic acid as standard [35]. $0.25 \mathrm{ml}$ of each sample (three replicates) was mixed with $1.25 \mathrm{ml} \mathrm{1/10}$ dilution of Folin-Ciocalteau's reagent. After 3 minutes, $1 \mathrm{ml}$ of $\mathrm{Na}_{2} \mathrm{CO}_{3}(7.5 \%$, w/v) were added and incubated for $30 \mathrm{~min}$.

The absorbance of all samples was measured at $765 \mathrm{~nm}$. The total phenolic content was expressed in $\mathrm{mg}$ of gallic acid equivalents (mg GAE)/g of dried extract by using the regression equation that was obtained from the calibration curve of the gallic acid standard. All determinations were performed 3 times.

\subsection{Total flavonoids contents}

Total flavonoid content of each extract was determined by aluminium trichloride $\left(\mathrm{AlCl}_{3}\right)$ method as described by Lamaison et al. [36]. $1 \mathrm{ml}$ aliquot of each extract dissolved in ethanol was added to $1 \mathrm{ml}$ of solution of $\mathrm{AlCl}_{3}$ $(2 \% \mathrm{w} / \mathrm{v})$. The mixture was vigorously shaken, and after $1 \mathrm{~h}$ of incubation, absorbance was taken at $420 \mathrm{~nm}$. Quercetin was used as the standard for the calibration curve. The flavonoid content was expressed as mg of quercetin equivalent $(\mathrm{QE})$ per gram dry weight of $P$. lentiscus berries extract.

\subsection{Antioxidant activity}

In this study, the antioxidant potential of the ethanolic extract of $P$. lentiscus berries was measured by different chemical assays: DPPH radical scavenging activity, ABTS test and reduction power activity. We compared the antioxidant capacity of the extract with BHT as reference.

\subsubsection{DPPH assay}

The antiradical activity of ethanolic extract was determined using the stable 2,2-diphenyl-1-picrylhydrazyl radical (DPPH.) [37]. $25 \mu \mathrm{L}$ samples of various concentrations of ethanolic extract were added to $975 \mu \mathrm{L}$ of ethanolic solution containing DPPH radicals $(60 \mu \mathrm{M})$ while butylatedhydroxytoluene (BHT) acted as a positive control, the absorbance of DPPH. radical solution without sample was measured as blank. All test tubes were incubated in a dark place at room temperature for 30 minutes. Then the absorbance was measured at $517 \mathrm{~nm}$. All determinations were carried out in triplicates. The disappearance of DPPH- was recorded and the percent inhibition of the DPPH. radical by sample is calculated as follows:

$$
\text { Inhibition Percent }=\left[\left(A_{b}-A_{s}\right) / A_{b}\right] \times 100 .
$$

Where $A_{b}$ is the absorbance of blank and $A_{s}$ is the absorbance of positive control or sample. Extract concentration providing $50 \%$ inhibition $\left(\mathrm{IC}_{50}\right)$ was calculated from the graph plotting inhibition percentage against extract concentration.

\subsubsection{ABTS + free radical scavenging activity}

The ABTS method is based on the reduction of the green ABTS radical cation $(7.00 \mathrm{mM})$ that was obtained by its oxidation with equal volume of potassium persulfate $(2.45 \mathrm{mM})$ [38], for $12-16 \mathrm{~h}$ at $4^{\circ} \mathrm{C}$ in the dark. ABTS + solution was diluted with ethanol to absorbance of $(1.00 \pm 0.02)$ at $734 \mathrm{~nm}$. Then, $25 \mu \mathrm{L}$ of the extract dilutions was mixed with $1 \mathrm{~mL} \mathrm{ABTS}^{+}$solution, the absorbance of reaction mixture was measured after $7 \min$ at $734 \mathrm{~nm}$. Tests were carried out in triplicate. ABTS + solution was used as blank sample, and BHT was used as positive control. As for the DPPH assay, ABTS scavenging ability was expressed as $\mathrm{IC}_{50}(\mathrm{mg} / \mathrm{l})$. The values of $\mathrm{IC}_{50}$ were 
determined as reported above. The inhibition percentage of ABTS radical was calculated using the following formula:

$$
\text { ABTS scavenging activity }(\%)=\left(\mathrm{A}_{0}-\mathrm{A}_{1}\right) / \mathrm{A}_{0} \times 100 .
$$

Where $\mathrm{A}_{0}$ is the absorbance of the control, and $\mathrm{A}_{1}$ is the absorbance of the sample.

\subsubsection{Reducing power}

The reducing power was determined according to the method of Oyaizu [39]. $0.125 \mathrm{ml}$ of ethanolic extract and BHT at different concentrations were mixed with $2.5 \mathrm{ml}$ of sodium phosphate buffer $(0.2 \mathrm{M}, \mathrm{pH}=6.6)$, and $2.5 \mathrm{ml}$ of potassium ferricyanide $(1 \%)$. The mixture was incubated at $50^{\circ} \mathrm{C}$ for $20 \mathrm{~min}$. Then, $2.5 \mathrm{ml}$ of $10 \%$ trichloroacetic acid was added to the mixture which was centrifuged for $10 \mathrm{~min}$ at $1500 \mathrm{rpm}$. The upper layer $(2.5 \mathrm{ml})$ was mixed with $2.5 \mathrm{ml}$ of distilled water and $0.5 \mathrm{ml}$ of $0.1 \%$ ferric chloride. The absorbance was measured at $700 \mathrm{~nm}$. Blank absorbance was read by replacing sample by ethanol. BHT was used as a positive control. The reducing power increases with the increase of absorbance. All determinations were carried out in triplicates. A higher absorbance indicates a higher reducing power. $\mathrm{IC}_{50}$ value $(\mathrm{mg} / \mathrm{l})$ is the effective concentration giving an absorbance of 0.5 for reducing power and was obtained from linear regression analysis.

\subsubsection{Statistical analysis}

Statistical comparisons were made with one way ANOVA followed by Tukey multiple comparison test. The level of significance was set at $P<0.05$. Statistical calculation was performed using SPSS 20.0 software. All the data were analyzed and expressed as mean \pm standard deviation of three separate determinations $(n=3)$.

\section{Results}

In the present study, the DPPH radical scavenging activity, ABTS radical scavenging activity and reducing power of $P$. lentiscus berries extract were investigated. The antioxidant activities of $P$. lentisus extract were also compared with that of reference synthetic antioxidant. In addition, the phytochemical analysis, phenolic compound and flavonoids content of ethanolic extract were carried out.

\subsection{Phytochemical screening}

Phytochemical screening was performed using standard protocols which showed the presence of phenolic compounds, flavonoids, antocyanins, leucanthocyanins, phlobotannins, tannins, saponins, terpenoids, proteins and mucilage with absence of alkaloids, quinones and carotenoids (Table 1).

\subsection{The total phenolic and flavonoid content}

Phenolic compounds are the largest group of phytochemicals and have been touted as accounting for most of the antioxidant activity of plants or plant products [40]. Several reports have shown a close relationship between total phenolic content and high antioxidant activity [41]. Total phenolic contents obtained were $955.28 \pm 0.125 \mathrm{mg}$ $\mathrm{GAE} / \mathrm{g}$ of the berries extract and total flavonoid contents obtained were $13.40 \pm 0.35 \mathrm{mg}$ QE/g of the berries extract for the P. lentiscus (Table 2).

\subsection{DPPH radical scavenging assay}

Plants rich in secondary metabolites, including phenolics, flavonoids and carotenoids, have antioxidant activity due to their redox properties and chemical structures [42], the DPPH radical scavenging method was used to 
Table 1

Phytochemical screening of $P$. lentiscus berries

\begin{tabular}{lc}
\hline Phytochemicals & P. lentiscus berries \\
\hline Phenolic compounds & + \\
Flavonoids & + \\
Anthocyanins & + \\
Leucanthocyanins & + \\
Phlobatannins & + \\
Tannins & + \\
Alkaloids & - \\
Carotenoids & - \\
Proteins & + \\
Mucilage & + \\
Saponins & + \\
Terpenoids & + \\
Quinones & - \\
\hline
\end{tabular}

(+): Present, (-): Absent.

Table 2

The content of total phenolics, flavonoids in P. lentiscus berries ethanolic extract

\begin{tabular}{lcc}
\hline & $\begin{array}{c}\text { Total phenolic content } \\
\text { (mg GAE/g extract) }\end{array}$ & $\begin{array}{c}\text { Total flavonoid content } \\
\text { (mg QE/g extract) }\end{array}$ \\
\hline $\begin{array}{l}\text { P. lentiscus berries } \\
\text { ethanolic extract }\end{array}$ & $955.28 \pm 0.125$ & $13.40 \pm 0.35$ \\
\hline
\end{tabular}

Data are expressed as mean \pm standard deviation of three different experiments.mg GAE/g: mg of gallic acid equivalent per g of lyophilized extract; mg QE/g: mg of quercetin equivalent per $\mathrm{g}$ of lyophilized extract.

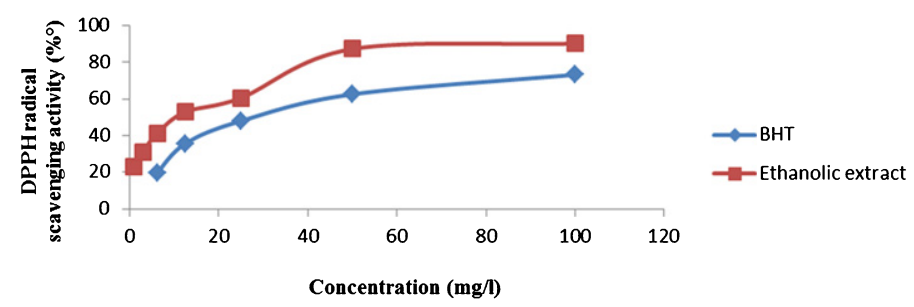

Fig. 1. Free radical scavenging capacities of BHT and P. lentiscus berries ethanolic extract measured in DPPH assay.

evaluate the antioxidant capacity of the berries extract, because the use of DPPH radical provides an easy, rapid and convenient method to evaluate the antioxidants and radical scavengers [43]. In the present study, P. lentiscus berries extract showed a strong effect in inhibiting DPPH, reaching up to $90.059 \pm 0.65 \%$ at concentration of $100 \mathrm{mg} / \mathrm{l}$. Figure 1 shows the dose response curve of DPPH radical scavenging activity of $P$. lentiscus compared with standard BHT. The concentration of the extract to scavenge $50 \%$ of the DPPH radical is called $\mathrm{IC}_{50}$ and lower $\mathrm{IC}_{50}$ values indicates higher antiradical activity. The $\mathrm{IC}_{50}$ value of $P$. lentiscus berries extract was $8.60 \pm 0.07 \mathrm{mg} / 1$ while the $\mathrm{IC}_{50}$ value of standard antioxidant BHT was $28.24 \pm 0.20 \mathrm{mg} / \mathrm{l}$ (Table 3). 
Table 3

Antioxidant activity expressed in $\mathrm{IC}_{50}(\mathrm{mg} / \mathrm{l})$ of ethanol extract of of $P$. lentiscus berries and BHT

\begin{tabular}{lrcc}
\hline Plant sample/Control & \multicolumn{1}{c}{ DPPH } & ABTS & Reduction power \\
\hline Berries ethanolic extract & $8.60 \pm 0.07^{\mathrm{b}}$ & $8.65 \pm 0.051^{\mathrm{a}}$ & $12.21 \pm 0.036^{\mathrm{b}}$ \\
BHT & $28.24 \pm 0.20^{\mathrm{a}}$ & $5.81 \pm 0.01^{\mathrm{b}}$ & $64.14 \pm 0.14^{\mathrm{a}}$ \\
\hline
\end{tabular}

Values in the same column followed by the same letter are not significantly different by the Tukey's multiple range test $(p<0.05)$. Data are the mean of three replicates.

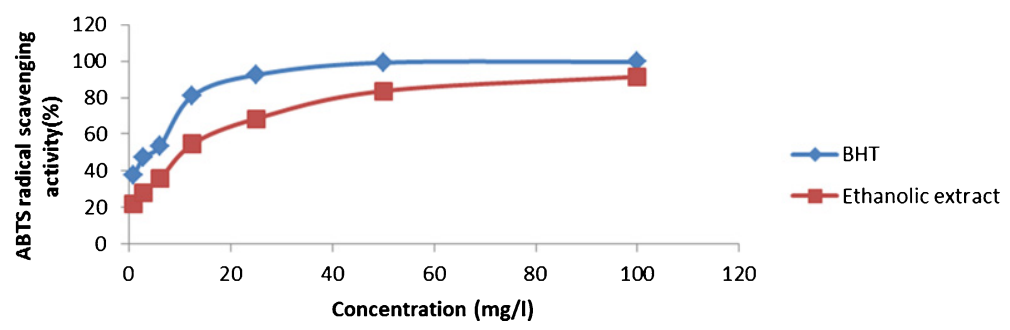

Fig. 2. Free radical-scavenging capacities of BHT and P. lentiscus berries ethanolic extract measured in ABTS assay.

\subsection{ABTS radical scavenging activity}

The ABTS assay is based on the inhibition of the absorbance of radical cation, $\mathrm{ABTS}^{+}$, which has a characteristic wavelength at $734 \mathrm{~nm}$, by antioxidants. Similar to DPPH, the decolorization of ABTS radical reflects the capacity of an antioxidant species to donate electron or hydrogen atoms to inactivate this radical cation [44]. ABTS results were in good agreement with DPPH method that the scavenging activity of the ethanolic extract was increased with the increasing concentration. The extract scavenged the ABTS radical in a dose dependent manner at concentration of 1-100 mg/l (Fig. 2). Furthermore, the results obtained in this study indicated that the berries ethanolic extract of $P$. lentiscus exhibited a high ABTS radical-scavenging activity and its percentage inhibition reached $91.45 \pm 0.14 \%$ at a concentration of $100 \mathrm{mg} / \mathrm{l}$, which appeared lower than of synthetic antioxidants BHT $\left(99.56 \pm 0.056 \%\right.$ ) for the same concentration, these findings were confirmed by calculating the $\mathrm{IC}_{50}$ values for the P. lentiscus berries extract $(8.65 \pm 0.051 \mathrm{mg} / \mathrm{l})$, which was found to be lower that of standard BHT $\left(\mathrm{IC}_{50}=5.81 \pm 0.01 \mathrm{mg} / \mathrm{l}\right)$.

\subsection{Reducing power}

Reducing power experiment is a good reflector of antioxidant activity of the plant. The plant having high reducing power generally reported to carry high antioxidant potential too. In this experiment, Ferric ions are reduced to ferrous ions with the color of the reaction mixture changes from yellow to bluish green. In reducing power assay, the dose-dependent curve of the plant extract at different concentrations $(1-100 \mathrm{mg} / \mathrm{l})$ was compared with that of BHT (Fig. 3). Ethanolic extract showed higher reducing power than that of the BHT. Reducing power potential of extract increase with the dose, however, extract exhibits height reducing power than that of BHT. The absorbance of the plant extract was varied from $0.39 \pm 0.008(1 \mathrm{mg} / \mathrm{l})$ to $0.87 \pm 0.001(100 \mathrm{mg} / \mathrm{l})$, whereas BHT was varied from $0.01 \pm 0.001(1 \mathrm{mg} / \mathrm{l})$ to $0.78 \pm 006(100 \mathrm{mg} / \mathrm{l})$. The $\mathrm{IC}_{50}$ value of the plant extract was $12.21 \pm 0.036 \mathrm{mg} / \mathrm{l}$ and that of BHT was $64.14 \pm 0.14 \mathrm{mg} / \mathrm{l}$ (Table 2). 


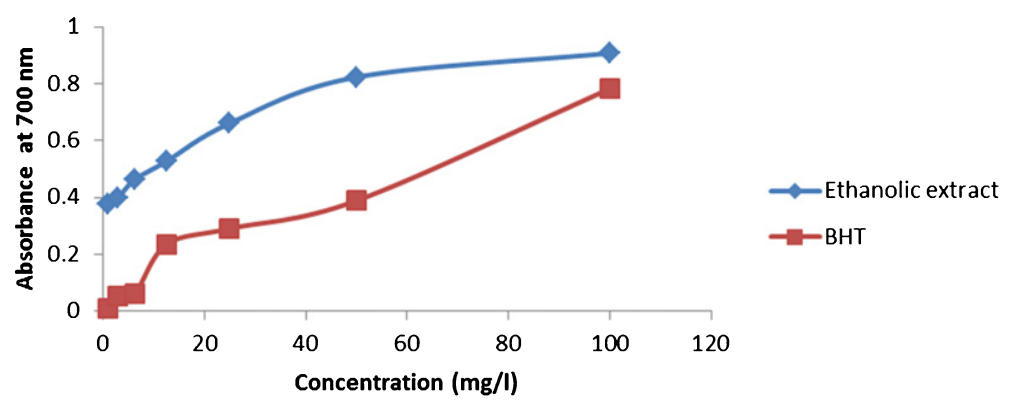

Fig. 3. Reduction power of berries ethanolic extract of P. lentiscus compared with that of BHT.

\section{Discussion}

The phytochemical screening was performed to identify the classes of chemical compounds present in the berries of $P$. lentiscus. Preliminary results have shown that $P$. lentiscus contains the majority of secondary metabolites, confirming the findings of Arab et al. [45]. We can say that almost all of bioactive molecules are present which proves their wealth and potentiality biological activities; they are responsible for the major activities including antioxidant activity; thus supporting the medicinal uses of this plant. Phenolic compounds have been detected in different parts of it [46], demonstrating that digallic acid (39) from fruits of $P$. lentiscushas anti-mutagenic properties. 1,2,3,4,6-Pentagalloyl glucose (45) and gallic acid from fruits of $P$. lentiscus were introduced as antioxidant and anti-mutagenic compounds [22]. Flavonoids were also isolated from aerial parts of P. lentiscus, quercetin-3-glucoside (56) was reported as the most abundant one [47]. Natural antioxidants like phenols, flavonoids and tannins possess potent antioxidant [48, 49]. Zitotni et al. [33] reported that phytochemical analysis showed that the major constituents of the extracts of P. lentiscus fruit were flavonoids, tannins, and anthocyanins, another authors found the anthocyanins, the flavonoids and triterpenes respectively in this plant [50, 51]. Similarly, the review of phytochemical screening realized by Hamad et al. [52] revealed the presence of unsaturated sterols and/or triterpenes, carbohydrates, flavonoids and tannins in P. lentiscus. Anthocyanins have been reported from some Pistacia species [53-55]. Cyanidin-3-O-glucoside and delphinidin-3-O-glucoside (63) have been detected in P. lentiscus berries and leaves [27, 50].

Plant phenols represent one of the major groups of compounds acting as primary antioxidants or free radical terminators. Thus, it was reasonable to determine their total amount in the selected plant extracts [56]. The results of these phytochemicals obtained in the present study, especially those of flavonoids and phenolic content, was shown to be higher than that found in some studies, the phenolic contents in berries were of $103.342 \pm 2.317 \mathrm{mg}$ GAE/g and 414.9 $\pm 3.0 \mathrm{mg}$ GAE/g, respectively found by Zitouni et al. [33] and Boutsari et al. [57]. Another recent study by Arab et al. [45] reported an abundance of phenolic compounds in fruits of P. lentiscus (61.34\%). In comparison with others authors, Zitouni et al. [33] found that the flavonoid content was $4.696 \pm 0.329$ (mg $\mathrm{CE} / \mathrm{g} \mathrm{DM}$ ) in berries of P. lentiscus. Author work reported that the total phenolic and flavonoid content in fruits extract of $P$. lentiscuswere $(205.79 \pm 6.51 \mathrm{mg}$ CatE/gE and $6.28 \pm 1.04 \mathrm{mg}$ RutE/gE), respectively [32]. The results of this study shown the higher total phenolic compounds content of $P$. lentiscus berries than cranberry berries from Canada [58]. The Total phenolic compound values of methanolic extracts of three berry fruits (blueberry, blackberry, and strawberry) growing in Nanjing, China, were found to be $9.44,5.58$, and $2.72 \mathrm{mg}$ gallic acid/g DW, respectively [59]. These differences in total phenolic contents could be due to genotypic and environmental variations (climate, location, temperature, fertility and diseases) within species, plant part tested, harvesting time and extraction procedure [60]. The presence of phenolic compounds account for the majority of antioxidant activity in plants. Flavonoids, including flavones, flavanols and condensed tannins, are plant secondary metabolites, the antioxidant activity of which depends on the presence of free $\mathrm{OH}$ groups, 
especially 3-OH. Plant flavonoids have antioxidant activity in vitro and also act as antioxidants in vivo [61, 62]. The presence of phenolic compounds account for the majority of antioxidant activity in plants, in which the antioxidant properties are mainly because of their redox potential, which allow them to act as reducing agents, hydrogen donators, metal chelators and singlet oxygen quenchers [63]. Flavonoids exhibit a variety of biological activities both in vitro and in vivo [64]. The flavonoids content reported in our study for P. lentiscus berries were higher than that reported in previous studies for other berries (cranberry) [58, 65]. The Total flavonoids content values of blueberry, blackberry and strawberry were found to be $24.38,3.99$ and $1.16 \mathrm{mg}$ catechin/g DW, respectively [59]. The type and variety of berries plants may account for differences in the results obtained as well as possible variations in the extraction conditions and type used, Geographic origin of plants, genotypes considered, environmental conditions (soil, climate) and maturity stage at harvest of plants berries. It is reported in literature that flavonoids show considerable antioxidant action on human health and fitness and act either through scavenging or chelating processes [66].

Several methods are available to measure the antioxidant activity of food and biological systems [67]. Due to the presence of different bioactive components with antioxidative potential in the berries extracts of $P$. lentiscus, three complementary methods (DPPH, ABTS radical scavenging activity and reducing power) have been used to investigate sample extract antioxidant activity. The improved ABTS method has been widely used to evaluate the total antioxidant capacities of both aqueous and lipophilic systems in vitro, while the DPPH method has been used for evaluating the scavenging activities of antioxidants in lipophilic systems [68]. The DPPH is a stable free radical, which has been widely used as a tool for estimating free radical scavenging activities of antioxidants [48]. Our results suggested that different concentration have different activities and maximum activity was observed at $100 \mathrm{mg} / \mathrm{l}$ concentration. The observed antioxidant of extracts may be due to the neutralization of free radicals (DPPH), either transfer of hydrogen atom or by transfer of an electron [69]. This significant scavenging ability in the above berries extract could be attributed to the presence of active phytoconstituents in them and their high content of phenols and flavonoids. Phytochemical studies indicated the presence of copious amounts of flavonoids, tannins and phenolics in the extracts of P. lentiscus, which could be responsible for the observed activity [51]. Zitouni et al. [33] reported that Tannins roots and fruits of P. lentiscus exhibited also high activity with $\mathrm{EC}_{50}$ of $0.090 \pm 0.011 \mathrm{mg} / \mathrm{ml}$ and $0.099 \pm 0.019 \mathrm{mg} / \mathrm{ml}$. BelyagoubiBenhammou et al. [70] reported that the results from various free radical scavenging systems revealed that the fruits of $P$. atlantica plant had significant antioxidant activity and free radical scavenging activity and the $\mathrm{EC}_{50}$ values of the DPPH radical scavenging activity of the ethyl acetate fraction found to be (14.64 mg Antioxidant/g DPPH) and $(49.21 \mathrm{mg} / \mathrm{g}$ ) for the butanolic extract. Flavonoids and phenolic acids are the most important groups of secondary metabolites and bioactive compounds in plants [27]. Some researchers have investigated the relationship between antioxidant activity and polyphenol content [71-74]. Polyphenol compounds are reported to be a good source of natural antioxidants [75]. The rich flavonoid plants could be a good antioxidant source that would help increase the overall antioxidant capacity of an organism and guard it against lipid peroxidation [76].

The presence of specific chemical compounds in the extract of P. lentiscus may inhibit the potassium persulfate activity and hence reduced the production of ABTS. Several other authors noted that there is a correlation between total phenolic content and ABTS scavenging activity of the plants extracts [77-78]. Previous studies $[53,79,80]$, showed that greater antioxidant potential of several Pistacia species extract could be related to the nature of phenolic compounds and their hydrogen ability. Cherbal et al. [81] reported that a strong correlation exists between the total phenolic content and the antioxidant properties of P. lentiscus extract, indicating that the phenol compounds play an important role in the beneficial effects of these medicinal plant. Plants containing flavonoids have been reported to possess strong antioxidant activities [82]. Higher total phenol and flavonoid contents lead to better radical scavenging activity [83]. Phenolic compounds and flavonoids have been reported to be associated with antioxidant action in biological systems, mainly due to their red-ox properties, which can play an important role in absorbing and neutralizing free radicals, quenching singlet and triplet oxygen, or decomposing peroxides [84]. 
The reducing capacity of a compound may serve as a significant indicator of its potential antioxidant activity. It was found that in general, the reducing power of the berries ethanolic extract was higher than that of the standard BHT, giving an indication in the potential higher antioxidant activity of the extract. Earlier study revealed the antioxidant activity of reduction power of $P$. atlantica fruit extract with an $\mathrm{IC}_{50}$ of $0.13 \pm 0.001 \mathrm{mg} / \mathrm{ml}[70]$. Also in another recent study conducted by Zitouni et al. [33] reported that the $\mathrm{IC}_{50}$ of P. lentiscus fruit metnanolic extract was $0.666 \pm 0.035 \mathrm{mg} / \mathrm{ml}$. Our results are in agreement with those of Atmani et al. [51], Djidel et al. [85] and Atmani et al. [86], which showed that P. lentiscus exhibited a great reducing power. Benhammou et al. [87] noted that the both extracts of $P$. lentiscus and $P$. atlantica leaves were characterized by a high reduction power. Reducing power may be due to the presence of polyphenols, which can donate electrons and scavenge free radicals by converting them into more stable products and can terminate the radical chain reaction [88]. The reducing power of the extract is an indicator of its antioxidant properties [89].

\section{Conclusion}

The phytochemical tests performed on the berries of $P$. lentiscus shows the presence of phenolic compounds, flavonoids, anthocyanins, leucoanthocyanins, phlobotannins, tanins, saponins, terpenoids, proteins and mucilage while alkaloids, quinones and carotenoids are absents. The present study revealed that the P. lentiscus berries extract was found to contain a high amount of total phenols, flavonoids. In the present study, we concluded that the ethanolic extract of $P$. lentiscus is a potential source of natural antioxidants to react against free radicals such as DPPH, ABTS and reduction power. This activity of the extract may be due to the total polyphenolic contents present in it. The phytochemical profile results showed that the plant extract has molecules with high potential for the development of new drugs with application in the treatment and prevention of various diseases. On the whole, it is interesting to note that the studied plants have, in fact, properties that may suggest applications in pharmaceutical industry and food. Our results also suggest that inclusion of antioxidant rich extract of P. lentiscus as a dietary supplementary has beneficial effects for human health. The data of the current work appear useful for further research aiming to chemically identify the specific compounds responsible for the antioxidant activities of $P$. lentiscus, further works are necessary to explore this medicinal plant in terms of isolation of this compound. In vivo antioxidant activity, anti-inflammatory activity and anticancer activity studies are also necessary.

\section{Conflict of interest}

None to report.

\section{References}

[1] Cheurfa M, Allem R. Study of hypocholesterolemic activity of Algerian Pistacia lentiscus leaves extracts in vivo. Rev Bras Farmacogn. 2015;25(2):142-44. DOI: 10.1016/j.bjp.2015.02.011

[2] Abe AE, de Oliveira CE, Dalboni TM, Chagas-Paula DA, Rocha BA, de Oliveira RB, Gasparoto TH, Da Costa FB, Campanelli AP. Anti-inflammatory sesquiterpene lactones from Tithonia diversifolia trigger different effects on human neutrophils. Rev Bras Farmacogn. 2015;25(2):111-16.

[3] Mehenni C, Atmani-Kilani D, Dumarçay S, Perrin D, Gérardin P, Atmani D. Hepatoprotective and antidiabetic effects of Pistacia lentiscus leaf and fruit extracts. J Food Drug Anal. 2016;24(3):653-69. DOI: 10.1016/j.jfda.2016.03.002

[4] Lemouchi R, Selles C, Medjdoub H, Tabti B. Assessment of possible efficacy of aqueous leaves extract of Psoralea bituminosa L. for anti-hyperglycaemic activity. Asian Pac J Trop Dis. 2015;5(7):575-8.

[5] Janakat S, Al-Merie H. Evaluation of hepatoprotective effect of Pistacia lentiscus, Phillyrea latifolia and Nicotiana glauca. J Ethnopharmacol. 2002;83(1-2):135-8.

[6] Morita M, Naito Y, Yoshikawa T, Niki E. Antioxidant capacity of blueberry extracts: Peroxyl radical scavenging and inhibition of plasma lipid oxidation induced by multiple oxidants. J Berry Res. 2017;7:1-9.DOI:10.3233/JBR-170152 
[7] Pissard A, Lateur M, Baeten V, Magein H, Dupont P, Tabart J, Kevers C, Pincemail J. Determination of total phenolic compound content and antioxidant activity in cherry species and cultivars. J Berry Res. 2016;6(1):81-91. DOI:10.3233/JBR-150109

[8] Pistollato F, Giampieri F, Battino M. The use of plant-derived bioactive compounds to target cancer stem cells and modulate tumor microenvironment. Food Chem Toxicol. 2015;75:58-70. DOI: 10.1016/j.fct.2014.11.004

[9] Oh YS. Bioactive compounds and their neuroprotective effects in diabetic complications. Nutrients. 2016;8(8):472. DOI: 10.3390/nu8080472

[10] Rawani A, Pal S, Chandra G. Evaluation of antimicrobial properties of four plants extracts against human pathogens. Asian Pac J Trop Biomed. 2011;1:S71-5.

[11] Rojas A, Hernandez L, Pereda-Miranda R, Mata R. Screening for antimicrobial activity of crude drug extracts and pure natural products from Mexican medicinal plants. J Ethnopharmacol. 1992;35(3):275-83. DOI:10.1016/0378-8741(92)90025-M

[12] Sies H. Strategies of antioxidant defense. Eur J Biochem. 1993;215(2):213-9.

[13] Giampieri F, Forbes-Hernandez TY, Gasparrini M, Alvarez-Suarez JM, Afrin S, Bompadre S, Quiles JL, Mezzetti B, Battino M. Strawberry as a health promoter: An evidence based review. Food Funct. 2015;6(5):1386-98. DOI: 10.1039/c5fo00147a

[14] Grice HC. Safety evaluation of butylatedhydroxytoluene (BHT) in the liver, lung and gastrointestinal tract. Food ChemToxicol. 1986;24(10-11):1127-30.

[15] Wichi HP. Enhanced tumor development by butylated hydroxyanisole (BHA) from the prospective effect on forestomach and oesophageal saquamous epithelium. Food Chem Toxicol. 1988;26:717-23.

[16] Willcox JK, Ash SL, George L. Antioxidants and prevention of chronic disease. Crit Rev Food Sci Nutr. 2004;44:275-95. DOI: $10.1080 / 10408690490468489$

[17] Halliwell B, Gutteridge JM. Free Radicals in Biology and Medicine. 4th edition, Oxford University Press, Oxford, UK; 2007.

[18] Cai Y, Luo Q, Sun M, Corke H. Antioxidant activity and phenolic compounds of 112 traditional Chinese medicinal plants associated with anticancer. Life Sci. 2004;74:2157-84. DOI:10.1016/j.1fs.2003.09.047

[19] Andrè C, Castanheira I, Cruz JM, Paseiro P, Sanches-Silva A. Analytical strategies to evaluate antioxidants in food: A review. Trends Food Sci Technol. 2010;21:229-46. DOI:10.1016/j.tifs.2009.12.003

[20] Bhattacharjee I, Chatterjee SK, Ghosh A, Chandra G. Antibacterial activities of some plants extracts used in Indian traditional folk medicine. Asian Pac J Trop Biomed. 2011;1:S165-9.

[21] Veesenmeyer JL, Hauser AR, Lisboa T and Rello J. Pseudomonas aeruginosa virulence and therapy: Evolving translational strategies. Crit Care Med. 2009;37(5):1777-86. DOI: 10.1097/CCM.0b013e31819ff137

[22] Abdelwahed A, Bouhlela I, Skandrani I, Valenti K, Kadrid M, Guiraud P, Steimand R, Mariotte AM, Ghedira K, Laporte F, Dijoux-Franca MG, Chekir-Ghedira L. Study of antimutagenic and antioxidant activities of Gallic acid and 1,2,3,4,6pentagalloylglucose from Pistacia lentiscus: Confirmation by microarray expression profiling. Chem Biol Interact. 2007;165(1):1-13. DOI: $10.1016 /$ j.cbi.2006.10.003

[23] Amhamdi H, Aouinti F, Wathelet JP, Elbachiri A. Chemical Composition of the Essential Oil of Pistacia lentiscus L. from Eastern Morocco. Rec Nat Prod. 2009;3(2):90-5.

[24] Charef M, Yousfi M, Saidi M, Stoccker P. Determination of the fatty acid composition of Acorn (Quercus), Pistacia lentiscus seeds growing in Algeria. J Am Oil Chem Soc. 2008;85:921-4.

[25] Castola V, Bighelli A, Casanova J. Intraspecific chemical variability of the essential oil of Pistacia lentiscus L. from Corsica. Biochem Systematic Ecol. 2000;28:79-88.

[26] Duru ME, Cakir A, Kordali S, Zengin H, Harmandar M, Izumi S, Hirata T. Chemical composition and antifungal properties of essential oils of three Pistacia species. FIT. 2013;74:170-6.

[27] Romani A, Pinelli P, Galardi C, Mulinacci N, Tattini M. Identification and quantification of galloyl derivatives, flavonoid glycosides and anthocyanins in leaves of Pistacia lentiscus L. Phytochem Anal. 2002;13(2):79-86.

[28] Dob T, Dahmane D, Chelghoum C. Chemical composition of the essential oils of Pistacia lentiscus L. from Algeria. J Essent Oil Res. 2006;18(3):335-8.

[29] Bampouli A, Kyriakopoulou K, Papaefstathiou G, Louli V, Krokida M, Magoulas K. Comparison of different extraction methods of Pistacia lentiscus var. chia leaves: Yield, antioxidant activity and essential oil chemical composition. J Appl Res Med Aromat Plants. 2014;1:81-91.

[30] Beghlal D, Cherif HS, Boubekeur S, Rebiai N, Chaouia C, Beghlal K, Zeghdaoui AH, Terkmane C, El Bairi K. Antioxidant activity, total phenolic content and chemical composition of Pistacia lentiscus (L.) from Algeria. J Chem Pharm Res. 2015;7:621-32.

[31] Aouinti F, Zidane H, Tahri M, Wathelet JP, El Bachiri A. Chemical composition, mineral contents and antioxidant activity of fruits of Pistacia lentiscus L. from Eastern Morocco. J Mater Environ Sci. 2014;5(1):199-206.

[32] Remilaa S, Atmani-Kilani D, Delemasure S, Connat JL, Azib L, Richard T, Atmani D. Antioxidant, cytoprotective, antiinflammatory and anticancer activities of Pistacia lentiscus (Anacardiaceae) leaf and fruit extracts. Eur J Integr Med. 2015;7:274-86. DOI:10.1016/j.eujim.2015.03.009 
[33] Zitouni A, Belyagoubi-Benhammou N, Ghembaza N, Toul F, Atik-Bekkara F. Assessment of phytochemical composition and antioxidant properties of extracts from the leaf, stem, fruit and root of Pistacia lentiscus L. Int J Pharmacognosy and Phytochem Res. 2016;8(4)627-633.

[34] Quezel P, Santa S. Nouvelle flore de l'Algérie et des régions désertiques méridionales. Editions du Centre National de la recherche scientifique. Tome II. Ed. CNRS, Paris; 1963.

[35] Singleton VL, Ortofer R, Lamuela-Raventos RM. Analysis of total phenols and other oxidation substrates and antioxidants by means of Folin-Ciocalteu reagent. In: Packer L. (ed). Methods in Enzymology. Orlando. Academic Press; 1999;152-78.

[36] Lamaison JLC, Carnet A. Teneurs en principaux flavonoïdes des fleurs de Crataegeus monogyna Jacq et de Crataegeus laevigata (Poiret D. C) en fonction de la végétation. Pharmaceutica Acta Helvetiae. 1990;65:315-20.

[37] Hazzit M, Baaliouamer A, Verssimo AR, Faleiro ML, Miguel MG. Chemical composition and biological activities of Algerian Thymus oils. Food Chem. 2009;116:714-21.

[38] Cavar S, Maksimovic M, Vidic D, Paric A. Chemical composition and antioxidant and antimicrobial activity of essential oil of Artemisia annua L. from Bosnia. Ind Crop Prod. 2012;37:479-85.

[39] Oyaizu M. Studies on product of browning reaction prepared from glucose amine. Jpn J Nutr. 1986;44:307-15.

[40] Nain P, Saini V, Sharma S. In-vitro antibacterial and antioxidant activity of Emblica officinalis leaves extract, Int J Pharm Pharm Sci. 2012;4:385-9.

[41] Farasat M, Khavari-Nejad RA, Nabavi SMB, Namjooyan F. Antioxidant activity, total phenolics and flavonoid contents of some edible green seaweeds from northern coasts of the Persian Gulf, Iran J Pharm Res. 2014,13:163-170.

[42] Baba SA, Malik SA. Determination of total phenolic and flavonoid content, antimicrobial and antioxidant activity of a root extract of Arisaema jacquemontii Blume. J Taibah Univ Sci. 2015;9:449-54.

[43] Nickavar B, Kamalinejad M, Izadpanah H. In vitro free radical scavenging activity of five Salvia species. Pak J Pharm Sci. 2007;20: 291-4.

[44] Olajuyigbe OO, Afolayan AJ. Phytochemical assessment and antioxidant activities of alcoholic and aqueous extracts of Acacia mearnsii de wild. Int J Pharm. 2011;7:856-61.DOI: 10.3923/ijp.2011.856.861

[45] Arab K, Bouchenak O, Yahiaoui K. Phytochemical study and evaluation of the antimicrobial and antioxidant activity of essential oils and phenolic compounds of Pistacia lentiscusL. J Fundam Appl Sc. 2014;6(1):79-93. DOI:10.4314/jfas.v6i1.7

[46] Bhouri W, Derbel S, Skandrani I, Boubaker J, Bouhlel I, Sghaier MB, Kilani S, Mariotte AM, Dijoux-Franca MG, Ghedira K, ChekirGhedira L. Study of genotoxic, antigenotoxic and antioxidant activities of the digallic acid isolated from Pistacia lentiscus fruits. Toxicol In Vitro. 2010;24:509-15. DOI: 10.1016/j.tiv.2009.06.024

[47] Kawashty SA, Mosharrafa SAM, El-Gibali M, Saleh NA. The flavonoids of four Pistacia species in Egypt. Biochem Syst Eco. 2000;28:915-7.

[48] Sanchez-moreno C. Review: Methods used to evaluate the free radical scavenging activity in foods and biological systems. Food Sci Technol Int. 2002;8:121-37.

[49] Zahin M, Farrukh A, Iqbal A. The in vitro Antioxidant activity and total phenolic content of four Indian medicinal plants. Int J Pharm Pharm Sci. 2009;1(1):88-95.

[50] Longo L, Scardino A, Vasapollo G. Identification and quantification of anthocanins in the berries of Pistacia lentiscus L. Phillyrea latifolia L. and Rubia peregrina L. Innov. Food Sci Emerg Tech. 2007;8(3):360-364. DOI:10.1016/j.ifset.2007.03.010

[51] Atmani D, Chaher N, Berboucha M, Ayouni K, Lounis H, Boudaoud H, Debbache N, Atmani D. Antioxidant capacity and phenol content of selected Algerian medicinal plants. Food Chem. 2009;112:303-9.

[52] Hamad HH, Ibrahim HH, Mariam HG, Mojahidul I. Comparative phytochemical and antimicrobial investigation of some plant growing in Al Jabal Al Akhdar. J Nat Prod Plant Resour. 2011;1(1):15-23.

[53] Tomaino A, Martorana M, Arcoraci T, Moteleone T, Giovinazzo C, Saija A. Antioxidant activity and phenolic profile of pistachio (Pistaciavera L., variety Bronte) seeds and skins. Biochim. 2010;92:1115-22.

[54] Bellomo MG, Fallico B. Anthocyanins, chlorophylls and xanthophylls in pistachio nuts (Pistacia vera) of different geographic origin. J Food Compos Anal. 2007;20:352-9.

[55] Wu X, Prior L. Identification and characterization of anthocyanins by high-performance liquid chromatography-electrospray ionization-tandem mass spectrometry in common foods in the United States: Vegetables, nuts, and grains. J Agric Food Chem. 2005;53(8):3101-13. DOI: 10.1021/jf0478861

[56] Parajuli S, Pun NT, Parajuli S, Jamarkatell-Pandit N. Antioxidant activity, total phenol and flavonoid contents in some selected medicinal plants of Nepal. JHAS. 2012;2(1):27-31.

[57] Botsaris G, Orphanides A, Yiannakou E, Gekas V, Goulas V. Antioxidant and antimicrobial effects of Pistacia lentiscus L. extracts in pork sausages. Food Technol Biotechnol. 2015;53(4):472-8. DOI: 10.17113/ftb.53.04.15.4051

[58] Abeywickrama G, Debnath SC, Ambigaipalan P, Shahid F. Phenolics of selected cranberry genotypes (Vaccinium macrocarpon Ait.) and their antioxidant efficacy. J Agric Food Chem. 2016;64(49):9342-51. DOI:10.1021/acs.jafc.6b04291 
[59] Huang WY, Zhang Hc, Liu WX, Li CY. Survey of antioxidant capacity and phenolic composition of blueberry, blackberry, and strawberry in Nanjing. J Zhejiang Univ Sci B. 2012;13(2):94-102. DOI: 10.1631/jzus.B1100137

[60] Shan B, Cai YZ, Sun M, Corke H. Antioxidant capacity of 26 spice extracts and characterization of their phenolic constituents. J Agric Food Chem. 2005;53(20):7749-59. DOI:10.1021/jf051513y

[61] Geetha S, Sai-Ram M, Mongia SS, Singh V, Ilavazhagan G, Sawhney RC. Evaluation of antioxidant activity of leaf extract of sea buckthorn (Hippophae rhamnoides L.) on chromium (VI) induced oxidative stress in albino rats. J Ethnopharmacol. 2003;87(2-3): 247-51.

[62] Shimoi k, Masuda S, Shen B, Furugori M, Kinae N. Radioprotective effects of antioxidative plant flavonoids in mice. Mutat Res. 1996;350(1):153-61.

[63] Le Marchand L. Cancer preventive effects of flavonoids: A review. Biomed Pharmacother. 2010;56(6):296-301.

[64] Lee JH, Kim GH. Evaluation of antioxidant and inhibitory activities for different subclasses flavonoids on enzymes for rheumatoid arthritis. J Food Sci. 2010;75:H212-7. DOI:10.1111/j.1750-3841.2010.01755.x

[65] Tulio AZ Jr, Jablonski JE, Jackson LS, Chang C, Edirisinghe I, Burton-Freeman B. Phenolic composition, antioxidant properties, and endothelial cell function of red and white cranberry fruits. Food Chem. 2014;157:540-52. DOI: 10.1016/j.foodchem.2014.02.047

[66] Kessler M, Ubeaud G, Jung L. Anti- and pro-oxidant activity of rutin and quercetin derivatives. J Pharm Pharmacol. 2003;55(1):131-42. DOI: $10.1211 / 002235702559$

[67] Ali SS, Kasoju N, Luthra A, Singh A, Sharanabasava H, Sahu A, Bora U. Indian medicinal herbs as sources of antioxidants. Food Res Int. 2008;41:1-15. DOI:10.1016/j.foodres.2007.10.001

[68] Singh S, Singh RP. In vitro methods of assay of antioxidants: An overview. Food Rev Int. 2008;24(4):392-415. DOI: $10.1080 / 87559120802304269$

[69] Naik GH, Priyadarsini KI, Satav JG, Banavalikar MM, Sohoni PP, Biyani MK, Mohan H. Comparative antioxidant activity of individual herbal components used in Ayurvedic medicine. Phytochem. 2003;63(1):97-104.

[70] Belyagoubi-Benhammou N, Belyagoubi L, El Zerey-Belaskri A, Atik-Bekkara F. In vitro antioxidant properties of flavonoid fractions from Pistacia atlantica Desf. subsp. atlantica fruit using five techniques. J Mater Environ Sci. 2014;6(4):1118-25.

[71] Al-Rimawi F, Abu-Lafi S, Abbadi J, Alamarneh AAA, Sawahreh RA, Odeh I. Analysis of phenolic and flavonoids of wild Ephedra alata PLANT extracts by lc/pda and lc/ms and their antioxidant activity. Afr J Tradit Complement Altern Med. 2017;14(2):130-41. DOI: 10.21010/ajtcam.v14i2.14

[72] Al-Rimawi F, Rishmawi S, Ariqat SH, Khalid MF, Warad I, Salah Z. Anticancer activity, antioxidant activity, and phenolic and flavonoids content of wild tragopogon porrifolius plant extracts. Evid Based Complement Alternat Med. 2016;2016:1-7. DOI: $10.1155 / 2016 / 9612490$

[73] Amensour M, Sendra E, Abrini J, Bouhdid S, Pérez-Alvarez JA, Fernández-Lòpez J. Total phenolic content and antioxidant activity of myrtle (Myrtus communis) extracts. Nat Prod Commun. 2009;4(6):819-24.

[74] Cheynier V. Polyphenols in foods are more complex than often thought. Am J Clin Nutr. 2005;81:223S-9S.

[75] Hagerman AE, Riedl KM, Jones GA, Sovik KN, Ritchard NT, Hartzfeld PW, Riechel TL. High molecular weight plant phenolics (tannis) as biological antioxidants. J Agric Food Chem. 1998;46(5):1887-92. DOI: 10.1021/jf970975b

[76] Sharififar F, Dehghn-Nudeh G, Mirtajaldini M. Major flavonoids with antioxidant activity from Teucrium polium L. Food Chem. 2009;112(4):885-8. DOI: 10.1016/j.foodchem.2008.06.064

[77] Kumar S, Sandhir R, Ojha S. Evaluation of antioxidant activity and total phenol in different varieties of Lantana camara leaves. BMC Res Notes. 2014;7:560. DOI: 10.1186/1756-0500-7-560

[78] Fidrianny I, Rahmiyani I, Komar RW. Antioxidant capacities from various leaves extracts of four varieties mangoes using DPPH, ABTS assays and correlation with total phenolic, flavonoid, carotenoid. Int J Pharm Pharm Sci. 2013;5:189-94.

[79] Hatamnia AA, Abbaspour N, Darvishzadeh R. Antioxidant activity and phenolic profile of different parts of Bene (Pistacia atlantica subsp. kurdica) fruits. Food Chem. 2014;145:306-11. DOI: 10.1016/j.foodchem. 2013.08.031

[80] Mahmoudi M, Ebrahimzadeh MA, Nabavi SF, Hafezi S, Nabavi SM, Eslami SH. Anti-inflammatory and antioxidant activities of gum mastic. Eur Rev Med Pharmacol Sci. 2010;14:765-9.

[81] Cherbal A, Kebeiche M, Madani K, El-Adawi H. Extraction and valorization of phenolic compounds of leaves of Algerian Pistacia lentiscus. Asian J Plant Sci. 2012;11:131-6. DOI: 10.3923/ajps.2012.131.136

[82] Soares JR, Dins TC, Cunha AP, Almeida LM. Anti-oxidants activity of some extracts of Thymus zygis. Free Radic Res. 1997;26: 469-78.

[83] Huang D, Ou B, Prior RL. The chemistry behind antioxidant capacity assays. J Agr Food Chem. 2005;53:1841-56.

[84] Zheng W, Wang SY. Antioxidant activity and phenolic compounds in selected herbs. J Agric Food Chem. 2001;49(11):5165-70.

[85] Djidel S, Khennouf S, Ameni D, Baghiani A, Arrar L, Charef N. Antioxidant proprieties of Pistacia lentiscus L. leaves extracts. Phcog Commn. 2013;3:28-34. 
[86] Atmani D, Chaher N, Ayouni K, Berboucha M. Antioxidant capacity of Pistacia lentiscus and Fraxinus angustifolia extracts and their fractions. Planta Med. 2011;7:1407. DOI: 10.1055/s-0031-1282788

[87] Benhammou N, Atik Bekkara F, Kadifkova Panovska T. Antioxidant and antimicrobial activities of the Pistacia lentiscus and Pistacia atlantica extracts. Afr J Pharm Pharma col. 2008;2:22-8.

[88] Rajamanikandan S, Sindhu T, Durgapriya D, Sophia D, Ragavendran P, Gopalakrishnan VK. Radical scavenging activity of ethanolic extract of Mollugo nudicaulis by in vitro assays. Ind J Pharm Educ Res. 2011;45:310-16.

[89] Mier S, Kaner J, Akiri B, Hadas SP. Determination and involvement of aqueous reducing compounds in oxidative defence systems of various senescing leaves. J Agric Food Chem. 1995;43:1813-7. 